\title{
Responding to the Challenge of Mental Health Recovery Policy
}

\author{
Lindsay G. Oades \\ University of Wollongong \\ Australia
}

\section{Introduction}

The movement towards recovery-oriented mental health service provision has emerged from growing consumer interest to define recovery in terms of personal experience, rather than symptom reduction. In many Western nations, this developing interest has helped to shape governmental health policy (Slade, Amering, \& Oades, 2008). Slade, Amering and Oades (2008) state that policy in mental health recovery has become widespread in the English speaking world. They make a distinction between clinical recovery and the more consumer defined view of personal recovery, arguing that the term 'recovery' has become increasingly visible in mental health services, referring to personal recovery. Rather than the traditional medical meaning of cure as the remission of symptoms, the term "recovery" is being used to describe the personal and transformational process of consumers living with mental illness (Andresen, Oades \& Caputi, 2003). The guiding principle for mental health policy in many predominantly English-speaking countries is mental health recovery, particularly now personal recovery: Australia (Australian Health Ministers, 2003), Canada (Piat \& Sabetti, 2009), England (Department of Health, 2001), Ireland (Mental Health Commission, 2005), New Zealand (Mental Health Commission, 1998) and the United States (New Freedom Commission on Mental Health, 2005). This policy consensus has now become professional rhetoric. Using England as just one example, the principles of recovery have been adopted by clinical psychology (British Psychological Society Division of Clinical Psychology, 2000), mental health nursing (Department of Health, 2006), occupational therapy (College of Occupational Therapists, 2006) and psychiatry (Care Services Improvement Partnership, Royal College of Psychiatrists, \& Social Care Institute for Excellence, 2007).

Slade, Amering and Oades (2008) use the term "rhetorical consensus" to refer to the consensus about the policy, which conceals the complexity and confusion around the term recovery. Since this article, further developments regarding mental health recovery have been impacting in European and Asian countries. Despite this increasing interest at the policy level, much of professional training remains symptom focussed, and many organisations continue on similar models.

To respond to the challenge of recovery policy it is important to have a clear definition of the phenomenon. It can then be measured. Services can then be developed based on the concept. Whilst this seems rudimentary- strong empirical work in this regard remains in its infancy. This chapter provides a descriptive overview of definitions of mental health 
recovery, and recovery oriented service provision. The first section of the chapter will define mental health recovery, including links to the science of wellbeing. Advances in measuring mental health recovery will be described. At an organisational level, mental health service providers (e.g. clinical mental health services, community organisations) have typically been symptom focused and have not celebrated the potential of consumers with mental disorders. The final section of the chapter will examine the development of recovery oriented service provision.

\section{What is mental health recovery?}

One of the most commonly cited definitions of personal recovery is as "a deeply personal, unique process of changing one's attitudes, values, feelings, goals, skills and roles. It is a way of living a satisfying, hopeful, and contributing life even with limitations caused by the illness. Recovery involves the development of new meaning and purpose in one's life as one grows beyond the catastrophic effects of mental illness" (Anthony, 1993). Slade, Amering and Oades (2008) assert that notwithstanding the significant increase in the use of the term 'recovery' in English speaking mental health systems, there is still a need for greater conceptual clarity. These authors refer to "clinical recovery" as a sustained remission of symptoms- which is consistent with the definition traditionally used in mental health services. They contrast this with "personal recovery" which emerged from patients who have lived with long-term illness emphasizes the individually defined and lived experience. Andresen, Oades and Caputi (2003) provide a definition consistent with personal recovery, known as psychological recovery, as the establishment of a fulfilling, meaningful life and a positive sense of identity founded on hopefulness and self-determination. This involves moving towards a preferred identity and a life of meaning - a framework where growth is possible and challenging fatalistic diagnoses such as schizophrenia, whose prognoses suggest little room for the possibility of clinical healing or a meaningful life (Andresen et al, 2003).

Slade et al (2008) report a previous consensus statement involving ten principles and descriptions of personal recovery as follows: (1) Self-direction - Consumers lead, control, exercise choice over, and determine their own path of recovery; (2) Individualised and PersonCentred - There are multiple pathways to recovery based on the individual's unique needs, preferences, and experiences; (3) Empowerment - Consumers have the authority to exercise choices and make decisions that impact on their lives and educated and supported in so doing; (4) Holistic - Recovery encompasses the varied aspects of an individual's life including mind, body, spirit, and community; (5) Nonlinear - Recovery is not a step-by-step process but one based on continual growth with occasional setbacks; (6) Strengths-Based Recovery focuses on valuing and building on the strengths, resilience, coping abilities, inherent worth, and capabilities of the individual; (7) Peer Support - The invaluable role of mutual support, in which consumers encourage one another in recovery is recognised and promoted; (8) Respect - Community, system, and societal acceptance and appreciation of consumers - including the protection of consumer rights and the elimination of discrimination and stigma - are crucial in achieving recovery; (9) Responsibility - Consumers have responsibility for their own self-care and journeys of recovery; and (10) Hope Recovery provides the essential and motivating message that people can and do overcome the barriers and obstacles that confront them.

Definitions of recovery have not remained static, and Resnick and Rosenheck (2006) highlighted the parallel themes and potential synergies between aspects of positive 
psychology, particularly strengths and their relationship to personal recovery. Other parallels include the emphasis on exploring phenomena other than illness. That is, recovery ideas that conceptualise the person's process of growth without using illness as the core framework. Positive psychology likewise does not use a negative starting point. Slade et al., (2008) report that an increased focus on recovery is being advocated as the guiding principle for mental health policy in many English-speaking countries, including Australia, England, Ireland and the United States of America. However, this momentum has not been matched by a clear conceptual framework or an agreed set of practices (Davidson, O'Connell, Tondora, Styron, \& Kangas, 2006). Oades, Andresen and Caputi (2011) examine the numerous parallels between positive psychological constructs including strengths, resilience, hope, meaning and wellbeing. They argue that positive psychology as a science of optimal human functioning may provide an "empirical bridge" between the lived experience of mental health consumers, and an empirical science that is consistent with a philosophy of growth and autonomy. These authors use psychological recovery to refer to five processes of hope, meaning, identity, finding personal meaning and taking responsibility of health and wellbeing. They report a five stage model of psychological recovery, in which people living with mental illness move from moratorium, to awareness, preparation, rebuilding to a final dynamic stage of growth. This stage model to be described further below, is part of a broader endeavour to enable the tighter definition and measurement of psychological recovery, to further assist the development and evaluation of recovery oriented service provision. Measurement issues of recovery are now explored.

\section{How is mental health recovery measured?}

There remains no universally-accepted criterion for operationalising the concept of recovery. As recovery is represented by consumers as a unique, personal journey, there has been a reticence to define it as an outcome, however, some recovery measures have been developed. Campbell-Orde et al. (2005) compiled the Compendium of Recovery Measures, which includes measures of individual recovery and measures of recovery-promoting environments. Measures of individual recovery may be categorised into two domains: those that focus on psychological processes of the person, and those that assess satisfaction with various life domains and treatment. Measures of the intrapersonal process of psychological recovery include hope and optimism, self-determination, resilience, positive identity and finding meaning and purpose in life. Examples of measures that could be considered to fit this definition include: the Recovery Assessment Scale (RAS; Corrigan et al.,1999), the Mental Health Recovery Measure (MHRM; Young and Ensing, 1999) the Stages of Recovery Instrument (STORI) and the Self Identified Stages of Recovery (SISR) (Andresen, Oades, Caputi, 2011). Moreover, whilst there is some resistance to the idea, there exists a substantial literature, based on qualitative research, describing recovery as taking place in stages or phases. Davidson and Strauss (1992), for example, identified four aspects of recovery of the sense of self in severe mental illness. These were "(1) discovering the possibility of possessing a more active sense of self, (2) taking stock of strengths and weaknesses and assessing possibilities for change, (3) Putting into action some aspects of the self and integrating the results as reflecting one's actual capabilities and (4) using an enhanced sense of self to provide some refuge to provide a resource against the effects of the illness and [such things as stigma]" (Davidson and Strauss, 1992, p. 134). 
Whilst Davidson and Strauss state that these four aspects do not necessarily occur in a linear fashion, but are related and overlapping, there is a logical order to the four aspects. Similarly three emotional stages of recovery were described by Baxter and Diehl (1998): (1) Recuperation, a stage of dependence following crisis; (2) Rebuilding, a time of building independence, and (3) Awakening, a time of building interdependence. Three phases were also posited by Young and Ensing (1999) in a model encompassing six aspects and numerous processes of recovery. The three phases of recovery were described as: Phase I, Overcoming "stuckness"; Phase II, Regaining what was lost and moving forward; and Phase III, Improving quality of Life (Young and Ensing, 1999). Spaniol et al. (2002) identified four phases of recovery in the literature: (1) Overwhelmed by the disability; (2) Struggling with the disability; (3) Living with the disability, and (4) Living beyond the disability. Spaniol et al. were able to place research participants in each of the first three phases, but not in the fourth phase. Tooth et al. (1997) and Lapsley et al. (2002) also found references to stages of recovery in large qualitative studies in Australia and New Zealand respectively.

Andresen, Oades and Caputi, $(2003 ; 2011)$ combined much of this work, and examined consumer narratives to develop the construct of psychological recovery and a five stage model of psychological recovery. They state that there are four psychological processes reported by people living with enduring mental illness: (1) managing hope (2) meaning and purpose (3) establishing or re-establishing a preferred identity (4) taking responsibility for health and wellbeing. These authors then report five stages across which these processes fluctuate (1) moratorium, where there is much confusion and life is effectively on hold, (2) awareness, in which the person gets an awareness that life could be different (3) preparation, in which the person starts to prepare to make changes to his or her life (4) rebuilding, in which the person commences making changes and finally (5), the growth stage in which the person experiences and meaningful life and preferred identity and continues to strive and grow, despite potentially still having mental health symptoms. There are several measurement tools associated with this model including the Stages of Recovery Instrument (STORI), and Self Identified Stage of Recovery (SISR). The former has been translated into four languages. This model is closely related to the Collaborative Recovery Model (Oades et al, 2005) which is one attempt to assist the development of recovery oriented service provison. This endeavour to operationalise mental health recovery policy is now considered.

\section{How do we develop recovery-oriented service provision?}

The phrases recovery-oriented practice and recovery-oriented service provision usually refer to practices and services that are informed by the principles underpinning personal recovery. This is part of the challenge of responding to mental health recovery policy. As has been argued, there is no established criterion on what exactly personal recovery is, and hence how to measure it, and the corollary of that is that there is debate about what constitutes recovery-oriented service provision. Moreover, there is confusion, and conflation of what is the personal lived experience of a personal with mental illness (i.e. personal or psychological recovery) and the services that may be oriented to supporting this process (i.e. recoveryoriented service provision).

Davidson, Tondora, Staeheli Lawless, O'Connell and Rowe (2009) describe ten principles of recovery-oriented community based care to assist with developing some clarity about 
recovery- oriented care. (1) Care is oriented to promoting recovery (2) Care is strengthsbased (3) Care is community- focussed (4) Care is person-driven (5) Care allows for reciprocity in relationships (6) Care is culturally responsive (7) Care is grounded in the person's life-context (8) Care addresses the socioeconomic context of the person's life (9) Care is relationally mediated; and (10) care optimises natural supports.

Like most organisational change, there is often resistance experienced. In this regard Davidson, O'Connell, Tondora, Styron, and Kangas (2006) had previously outlined the top ten concerns about recovery encountered. In increasing importance these are as follows: (10) Recovery is old news, (9) Recovery-oriented care adds to the burden of mental health practitioners who already are stretched thin by demands that exceed their resources, (8) "recovery" means the person is cured, (7) recovery in mental health is an irresponsible fad that sets people up for failure, (6) recovery happens for very few people with serious mental illness, (5) recovery only happens after, and as a result of, active treatment and cultivation of insight, (4) recovery can only be implemented with additional resources, through the introduction of new services, (3) recovery-oriented services are neither reimbursable nor evidence-based, (2) recovery approaches devalue the role of professional intervention, and (1) recovery increases provider exposure to risk and liability.

Davidson, Tondora, Staeheli Lawless, OConnell, and Rowe (2009) further describe the concept of a recovery guide. A recovery guide is similar to the concept of the recovery coaching, described by Oades et al (2009) in reference to the Collaborative Recovery Model. The Collaborative Recovery Model, a modularised model that guides systemic interventions, is proposed to facilitate the challenge of implementing recovery oriented service provision, and as discussed, is informed by positive psychology and positive organisational scholarship which provide a useful base upon which to build service reform and human growth. Oades, Crowe and Nguyen (2009) report that the CRM was originally developed as a model to assist practitioners to use evidence based skills with consumers in a manner consistent with the recovery movement (Deane et al, 2006). The model includes assumptions and practices that champion human growth, hope (Salgado et al, 2010), meaning and self-determination - issues that have not been the mainstay in the history of psychiatric practice.

Table 1 illustrates the two guiding principles and four components of the model, detailing the knowledge, skills and competencies required of practitioners.

\section{Guiding Principle \#1: Recovery as an individual process}

As shown in Table 1, the first principle emphasises the personal subjective ownership of the recovery process, including hopefulness and personal meaning. It covers issues related to personal identity, particularly the need to move beyond the illness and towards one's best possible self. Finally it encourages individuals to take responsibility for their own wellbeing (Andresen, Oades \& Caputi, 2003).

There are significant conceptual overlaps between Keyes' (2002) notion of flourishing and the idea of personal recovery as a journey that involves moving beyond illness, that is, living a meaningful life despite experiencing symptoms of illness. Within CRM, the focus of recovery concept is used to clarify the intervention or approach that is being utilised. For example, is the focus of a practitioner's team or unit mainly to remove or avoid symptoms, or is it to promote wellbeing? These are not fixed foci, and may change dependent on the illness. 


\begin{tabular}{|c|c|c|c|}
\hline Module & Knowledge Domains & $\begin{array}{l}\text { Protocol, Skills and } \\
\text { Attitudes }\end{array}$ & Competency \\
\hline $\begin{array}{l}\text { Recovery as an } \\
\text { individual } \\
\text { process } \\
\text { (Guiding } \\
\text { Principle 1) }\end{array}$ & $\begin{array}{l}\text { Psychological recovery as } \\
\text { a staged individual } \\
\text { process involving: (i) hope } \\
\text { (ii) meaning (ii) identity } \\
\text { (iv) responsibility } \\
\text { The "system of recovery" } \\
\text { concept } \\
\text { The "focus of recovery" } \\
\text { concept }\end{array}$ & $\begin{array}{l}\text { Protocol: Self } \\
\text { Identified Stage of } \\
\text { Recovery: } \\
\text { Attitude: A "growth } \\
\text { mindset" - } \\
\text { hopefulness towards } \\
\text { consumers' ability to } \\
\text { set, pursue and attain } \\
\text { personally valued life } \\
\text { goals }\end{array}$ & $\begin{array}{l}\text { Employs the } \\
\text { principle, in all } \\
\text { interactions and } \\
\text { across all protocols, } \\
\text { that psychological } \\
\text { recovery from } \\
\text { mental illness is an } \\
\text { individualised } \\
\text { process }\end{array}$ \\
\hline $\begin{array}{l}\text { Collaboration } \\
\text { and autonomy } \\
\text { support } \\
\text { (Guiding } \\
\text { Principle 2) }\end{array}$ & $\begin{array}{l}\text { Working alliance } \\
\text { Power and empowerment } \\
\text { Relationship rupture } \\
\text { Autonomy support } \\
\text { Barriers to collaboration } \\
\text { Working with relationship } \\
\text { dynamics }\end{array}$ & $\begin{array}{l}\text { Skill: Develop and } \\
\text { maintain a working } \\
\text { alliance } \\
\text { Attitude: Positive } \\
\text { towards genuine } \\
\text { collaboration }\end{array}$ & $\begin{array}{l}\text { Employs the } \\
\text { principle, in all } \\
\text { interactions and } \\
\text { across all protocols, } \\
\text { of maximum } \\
\text { collaboration and } \\
\text { support of } \\
\text { consumer } \\
\text { autonomy } \\
\end{array}$ \\
\hline $\begin{array}{l}\text { Change } \\
\text { enhancement } \\
\text { (Component 1) }\end{array}$ & $\begin{array}{l}\text { Stage of psychological } \\
\text { recovery } \\
\text { Decisional balance } \\
\text { Motivational readiness } \\
\text { and resistance } \\
\text { Psychological needs } \\
\text { Importance and } \\
\text { confidence } \\
\text { Fixed versus growth } \\
\text { mindset }\end{array}$ & $\begin{array}{l}\text { Protocol: Motivational } \\
\text { interviewing, } \\
\text { particularly decisional } \\
\text { balance } \\
\text { Skill: Use decisional } \\
\text { balance techniques } \\
\text { appropriate to assist } \\
\text { consumer to clarify } \\
\text { ambivalence } \\
\text { regarding change } \\
\text { Attitude: To take } \\
\text { partial responsibility } \\
\text { for role in } \\
\text { interactional aspects } \\
\text { of motivation }\end{array}$ & $\begin{array}{l}\text { Enhances consumer } \\
\text { change by skilful } \\
\text { use of motivational } \\
\text { enhancement that is } \\
\text { appropriate to the } \\
\text { stage of recovery of } \\
\text { the consumer }\end{array}$ \\
\hline $\begin{array}{l}\text { Collaborative } \\
\text { strengths and } \\
\text { values } \\
\text { (Component 2) }\end{array}$ & $\begin{array}{l}\text { Values clarification } \\
\text { Values use } \\
\text { Strengths identification } \\
\text { Strengths use }\end{array}$ & $\begin{array}{l}\text { Protocol: "Camera” } \\
\text { values and strengths } \\
\text { clarification method } \\
\text { Skill: Assist a } \\
\text { consumer to elicit } \\
\text { personal values and } \\
\text { strengths and assess } \\
\text { how well they have } \\
\text { been implemented } \\
\text { recently }\end{array}$ & $\begin{array}{l}\text { Assists consumers } \\
\text { to clarify values and } \\
\text { strengths and use } \\
\text { them in the here } \\
\text { and now }\end{array}$ \\
\hline
\end{tabular}




\begin{tabular}{|c|c|c|c|}
\hline Module & Knowledge Domains & $\begin{array}{l}\text { Protocol, Skills and } \\
\text { Attitudes }\end{array}$ & Competency \\
\hline & & $\begin{array}{l}\text { Attitude: To value } \\
\text { reflective exercises } \\
\text { notwithstanding } \\
\text { current difficulties or } \\
\text { symptoms }\end{array}$ & \\
\hline $\begin{array}{l}\text { Collaborative } \\
\text { life visioning } \\
\text { and goal } \\
\text { striving } \\
\text { (Component 3) }\end{array}$ & $\begin{array}{l}\text { Personal life vision } \\
\text { Valued directions } \\
\text { Goal identification, setting } \\
\text { and striving } \\
\text { Meaning/manageability } \\
\text { trade-off } \\
\text { Autonomous goals } \\
\text { Approach and avoidance } \\
\text { Goals } \\
\text { Proximal and distal goals }\end{array}$ & $\begin{array}{l}\text { Protocol: "Compass" } \\
\text { vision and goal } \\
\text { striving method } \\
\text { Skill: Elicit meaningful } \\
\text { vision and } \\
\text { manageable goals } \\
\text { Attitude: To be } \\
\text { persistent in the face } \\
\text { of obstacles }\end{array}$ & $\begin{array}{l}\text { Persists flexibly and } \\
\text { collaboratively with } \\
\text { the components } \\
\text { within the Compass } \\
\text { to assist recovery by } \\
\text { way of the } \\
\text { development of an } \\
\text { integrated } \\
\text { meaningful life } \\
\text { vision, valued } \\
\text { directions, and } \\
\text { manageable goals, } \\
\text { which provide a } \\
\text { broader purpose for } \\
\text { actions. }\end{array}$ \\
\hline $\begin{array}{l}\text { Collaborative } \\
\text { action planning } \\
\text { and monitoring } \\
\text { (Component } 4 \text { ) }\end{array}$ & $\begin{array}{l}\text { Health behaviour change } \\
\text { Action planning } \\
\text { Homework } \\
\text { Self-efficacy } \\
\text { Monitoring } \\
\text { Self-management }\end{array}$ & $\begin{array}{l}\text { Protocol: "MAP" } \\
\text { action planning } \\
\text { method } \\
\text { Skill: To assist with } \\
\text { the development of } \\
\text { comprehensive action } \\
\text { plans } \\
\text { Attitude: To value } \\
\text { "small actions" } \\
\text { between the meetings } \\
\text { of staff and consumers } \\
\text { (between session } \\
\text { activity) }\end{array}$ & $\begin{array}{l}\text { Systematically and } \\
\text { collaboratively } \\
\text { assigns actions, and } \\
\text { monitors progress } \\
\text { toward action } \\
\text { completion and } \\
\text { goals, to enhance } \\
\text { self-efficacy of } \\
\text { consumer }\end{array}$ \\
\hline
\end{tabular}

Table 1. Training and Coaching Competencies for Collaborative Recovery Model

\section{Guiding Principle \#2: Collaboration and autonomy support}

This principle emphasises important aspects of the working alliance in assisting human growth. Autonomy support as outlined in Ryan, Huta and Deci's (2008) self-determination theory, underscores the importance of autonomy to wellbeing. This is particularly salient in mental health contexts due to the history of paternalism and control that has pervaded so many aspects of the systems and patient care (Andresen, Oades \& Caputi, 2003).

There is substantial evidence regarding the association of the strength of the working alliance between the mental health worker and the person being supported in recovery and the degree of engagement and recovery outcomes (Martin, Garske \& Davis, 2000). However, 
maintaining a strong working alliance often requires the mental health worker to: manage interpersonal strains or alliance ruptures, reflect on his/her own reactions to the dynamics of the working relationship (e.g. increased frustration, desire to fix things or rescue the person, etc), and maintain professional boundaries whilst striving to remain present with the person they are supporting. This is important as it encourages the worker to track and adjust her/his approach as required (e.g. rebuild trust, establish safety, confront, explore feelings, etc), particularly in light of the sometimes subtle changes that can occur in the relationship. As CRM is growth and future focused, it is conceptualised as a strengths-based coaching model, in which the relationships are coaching relationships rather than counseling relationships (Oades, Crowe, Nguyen, 2009)..

\section{CRM Component \#1: Change enhancement}

This component recognises that many people (including consumers, carers and practitioners) within the context of enduring mental illnesses such as schizophrenia tend not to believe that positive change is possible. Change enhancement draws on skills from motivational interviewing, and directly challenges fixed mindsets (Dweck, 2006), regarding the potential for change. This component of the model also highlights the importance of intrinsic motivation and the personal meanings underpinning human change. It aims to shift both attitudes and beliefs about the potential for change.

\section{Component \#2: Collaborative Strengths and Values}

The clarification and use of personal strengths and values is central to the model, and is the most popular component for consumers and practitioners alike. Whilst Rapp's (1998) strengths model is well known to mental health practitioners in a case management context, the CRM predominantly draws from contemporary research on character strengths, values and committed action (e.g. Petersen \& Seligman, 2004; Hayes, 2004).

\section{Component \#3: Collaborative life visioning and goal striving}

This third component assumes that despite adversity, a person is still capable of developing a vision for life. The vision involves articulating their best possible self and striving towards approach goals that are consistent with their personal values and while using their strengths. Clarke et al (2006) describe the goal technology that has been used to operationalise the goal component of CRM. The Collaborative Goal Technology (CGT) uses a range of evidence-based practices in goal setting (e.g. goals being specific and time limited) to assist mental health practitioners and consumers to collaboratively develop goals. In a subsequent study, Clarke, Crowe et al., (2009) found that practitioners trained in CRM, which included the CGT, were more likely to apply these evidence-based principles. Additionally, Clarke and colleagues (Clarke, Oades et al, 2009) in another investigation of CRM found that the goal attainment of people with enduring mental illness mediated the relationship between the distress caused by their symptoms and their perception of personal recovery. This finding suggests that goals are central to the recovery process and is consistent with the growth philosophy of the recovery movement. Positive psychology research continues to deepen our understanding of effective goal striving and its relationship to wellbeing (Brandtstadter, 2006).

\section{Component \#4: Collaborative action planning and monitoring}

The fourth and final component of CRM is informed by research on the role of homework in cognitive-behavioural therapies (Kazantzis, Deane \& Ronan, 2000). The term "action 
planning" is used in CRM because it does not carry the somewhat negative connotations of the word homework, which often stem from unhappy school experiences. Meta-analyses have found that therapy outcomes are significantly better for those who receive and complete homework assignments (Kazantzis, Whittington \& Dattilio, 2010). Although this research has mostly focused on the treatment of depression and anxiety, there is increasing evidence of its importance in treating persistent and recurring mental illnesses such as schizophrenia (Deane, Glaser, Oades \& Kazantzis, 2005; Kelly \& Deane, 2009). Working on agreed actions between meetings is thus an essential ingredient of CRM.

\section{The Collaborative Recovery Model as a Coaching Model}

The CRM has been conceptualised as a strength-based person-centred coaching model (Oades, Crowe \& Nguyen, 2009). The Life Journey Enhancement Tools (LifeJET) (Oades \& Crowe, 2008) have been designed to operationalise key components of the CRM delivered in a coaching style, where the relationship is more person-centred and focused on personal goals (rather than clinician-centred and focused on clinical goals). Based on the root metaphor of a journey (of recovery), the protocols are called the Camera, Compass and MAP (see Figures 2 to 4), and are designed to stimulate future-oriented and hope-inducing activities. The Camera, Compass and MAP are modularized tools. Thus while it is preferable for them to be used in sequence they can be used alone.

The Camera is used to help the individuals to identify valued life domains and strengths, examine the extent to which these have recently been pursued, and to focus their attention on areas of potential change.

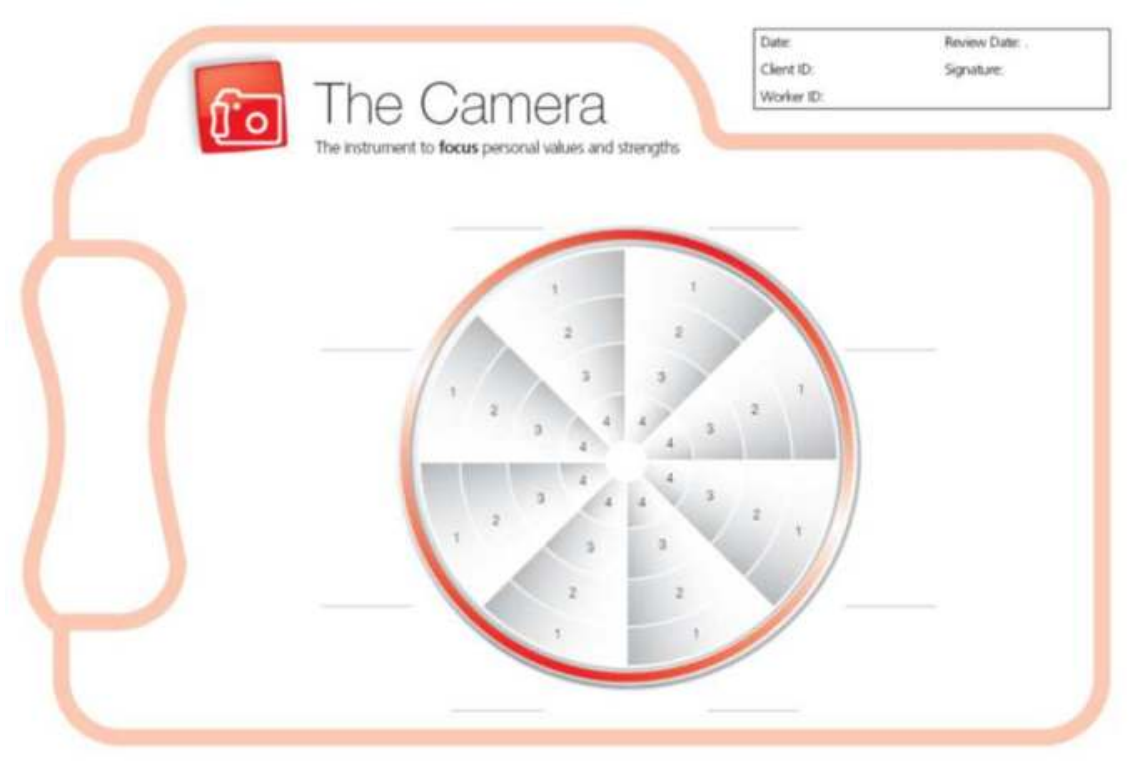

Fig. 1. The Camera values and strengths use coaching tool 
The Compass evolved from the previously mentioned goal technology (Clarke et al, 2006). It is used to assist people to link their values with their goals, to quantify relative goal importance and to identify different levels of potential attainment. The Compass enables ratings of successful goal pursuit as a function of importance and attainment. Goal attainment weighted by perceived importance can be calculated as a numeric index if desired.

Last, the MAP (an abbreviation for My Action Plan) is an action-planning tool used to assist with homework setting for goal attainment tasks.

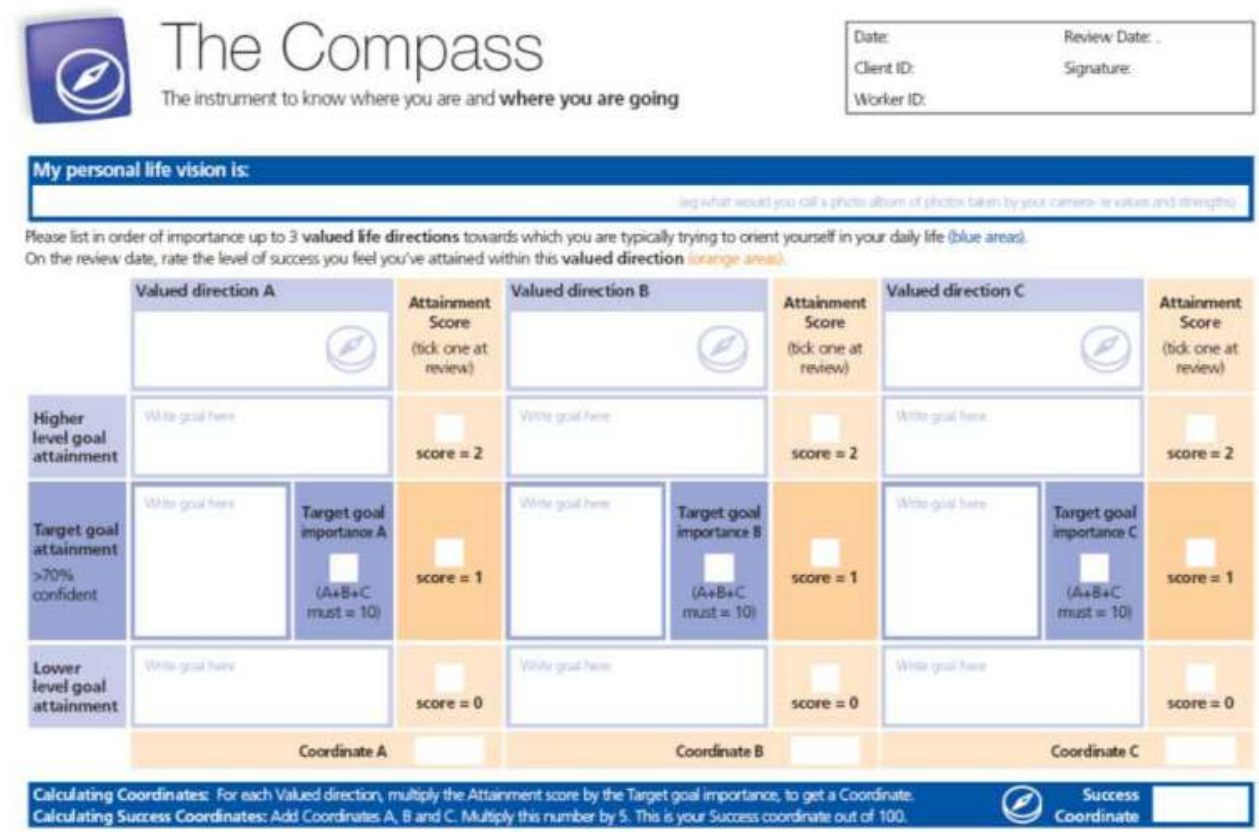

Fig. 2. The Compass valued direction and goal striving coaching tool

\section{The Collaborative Recovery Model as a Systemic Intervention}

Unlike many discrete and individual positive psychological interventions (Magyar-Moe, 2009) the Collaborative Recovery Model (CRM) (Oades et al, 2005), is a broad systemic framework guiding a range of interventions with consumers, carers, staff and organisational systems. The systemic nature of the interventions is imperative given the ingrained culture and history of psychiatric service provision. As Park and Petersen (2003) assert, positive institutions enable people to use their positive traits such as strengths and values, which in turn yields positive experiences and positive emotions. In mental health services, organisations require change to enable staff and consumers to utilise strengths, to enable the possibility of the benefits of positive emotions. Without such comprehensive change, recovery oriented services are unlikely to succeed. The CRM has been developed to assist with recovery-oriented service provision for people with enduring mental illness, and is informed by the principles, evidence and practices of positive psychology and positive organisational scholarship (Cameron, Dutton \& Quinn, 2003). 


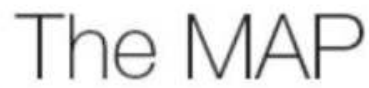

My Action Plan: The instrument to plan what to do next

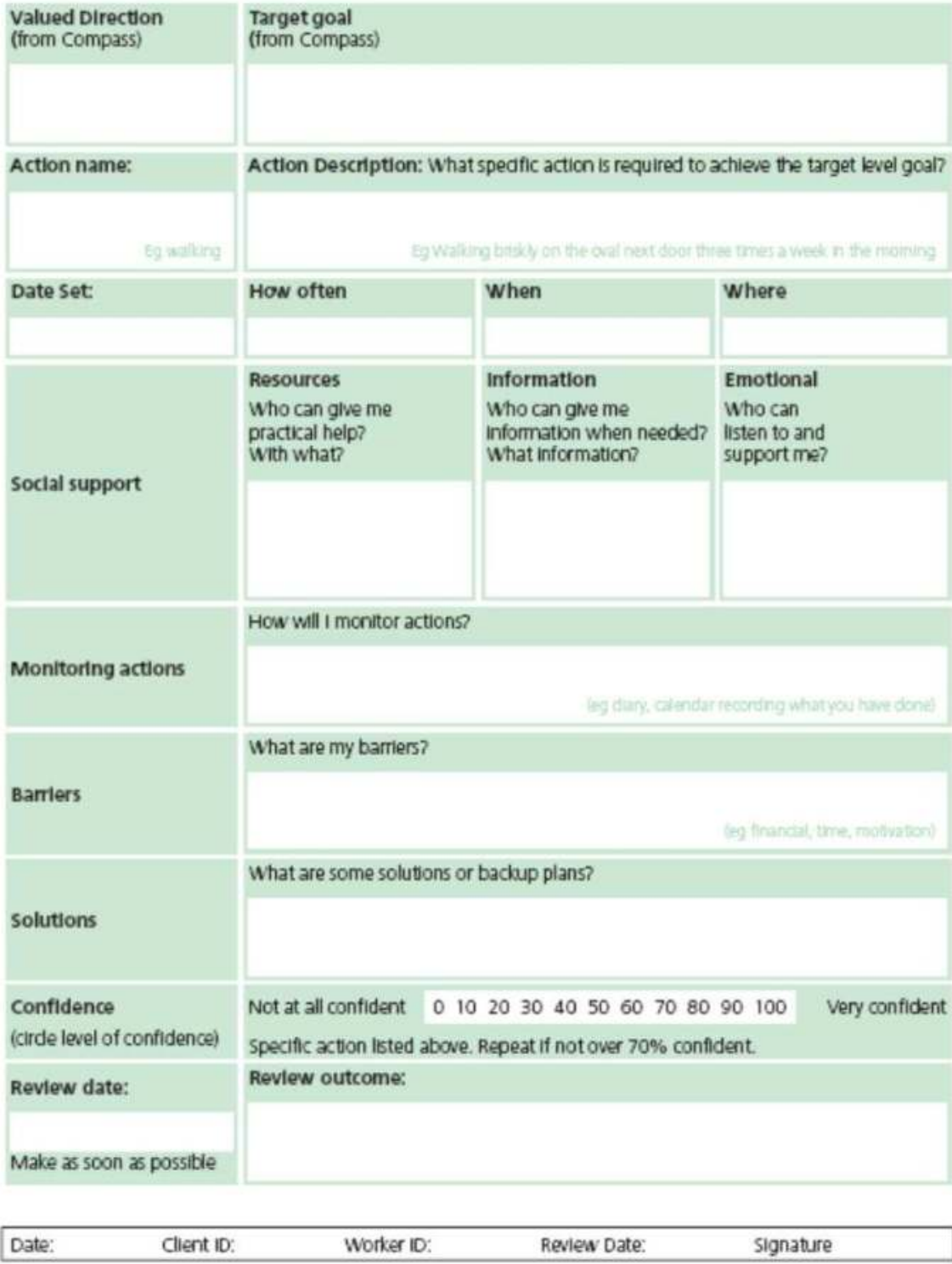

Fig. 3. The MAP action planning coaching tool 
The relationship between mental health workers and the individual's wider support system is central to the recovery process. From a Collaborative Recovery perspective this system includes four parts nested in a broader community. The four interlinked parts are self of consumer, family carers, staff members and organisations (e.g., treatment services) in the community.

Currently, there is research and practice being conducted using the LifeJET tools and CRM principles in all four parts of the mental health system. The extent to which that community encourages social inclusion and non-stigmatising attitudes can greatly support an individual's recovery (e.g., Quinn \& Knifton, 2005). Similarly, mental health organisations that are attempting to deliver recovery-oriented treatment may also need to make wider "systems" changes to do so successfully.

The CRM is deliberately being developed as a systemic intervention rather than one restricted to solely focusing on individual interventions with clients. The guiding principles, components and LifeJET protocol may be used for the self-development of individuals (selfcoaching), used as part of a practitioner-client coaching relationship (practitioner coaching), used for carer recovery (carer coaching) and used at the organisational level, which may include practitioners coaching other practitioners (coaching) towards personal and professional development. This comprehensive systems intervention is seen as necessary to bring about the systemic and cultural transformation needed to generate recovery oriented service provision.

\section{Conclusion}

Mental health recovery policy, based on definitions of personal recovery from people living with mental illness, has become mainstream in most English speaking nations, and is growing in popularity across Europe and Asia. The challenge remains however as to gaining (a) more consensus about the concept referring to varied consumer experience (b) improved ways to measure the concept and (c) improve ways and organisaitonal support to develop services based around the concept, with the need for individual tailoring. This transformation is more profound than the development of "new interventions to treat mental illness". Rather it refers to a major reconsideration of the endeavour itself, a review of what is possible, and a major transformation of the mental health workforce. The Collaborative Recovery Model (CRM) is one example of an attempt towards this endeavour.

\section{References}

Andresen, R., Caputi, P., \& Oades, L. G. (2010). Do clinical outcome measures assess consumer-defined recovery? Psychiatry Research, 177, 309-317.

Andresen, R., Oades, L. G., \& Caputi, P. (2003). The experience of recovery from schizophrenia: Towards an empirically validated stage model. Australian and New Zealand Journal of Psychiatry, 37, 586-594.

Andresen, R, Oades, L. G. Caputi, P. (2011). Psychological Recovery: Beyond Mental Illness. Chichester: Wiley Blackwell.

Anthony W.A. (1993). Recovery from mental illness: the guiding vision of the mental health system in the 1990s. Innovations and Research 2,17-24. 
Anthony, W. A., Cohen, M., Farkas, M., \& Cohen, B. F. (2000). Clinical care update: The chronically mentally ill. Case management-more than a response to a dysfunctional system. Community Mental Health Journal, 36, 97-105.

Australian Health Ministers (2003). National Mental Health Plan 2003-2008. Australian Government: Canberra.

Baumeister, R.R., \& Vohs, K.D. (2002). The pursuit of meaningfulness in life. In C.R. Snyder \& S.J. Lopez (eds)., Handbook of Positive Psychology, pp, 459-471.

Baxter E.A. \& Diehl S. (1998). Emotional stages: Consumers and family members recovering from the trauma of mental illness. Psychiatric Rehabilitation Journal, 21:349-355.

Brandtstadter, J. (2006). Adaptive resources in later life: Tenacious goal pursuit and flexible goal

British Psychological Society Division of Clinical Psychology (2000). Recent Advances in Understanding Mental Illness and Psychotic Experiences. British Psychological Society: Leicester.

Cameron, K., Dutton, J. E., and Quinn, R. E. (eds.). (2003). Positive Organizational Scholarship: Foundations of a New Discipline. San Francisco: Berrett-Koehler Publishers.

Campbell-Orde, T., Chamberlin, J., Carpenter, J., et al (2005) Measuring the Promise: A Compendium of Recovery Measures, Vol. II. Human Services Research Institute Evaluation Center.

Care Services Improvement Partnership, Royal College of Psychiatrists \& Social Care Institute for Excellence (2007). A Common Purpose: Recovery in Future Mental Health Services. CSIP: Leeds.

Carver, C., \& Scheier, M. (1990). Origins and function of positive and negative affect: A control process review. Psychological Review, 97, 19-35.

Clarke, S. P., Crowe, T. P., Oades, L. G., \& Deane, F. P. (2009). Do goal setting interventions improve the quality of goals in mental health services? Psychiatric Rehabilitation Journal, 32(4), 292-299.

Clarke, S. P., Oades, L.G., Crowe, T. P., \& Deane, F. P. (2006). Collaborative Goal Technology: Theory and Practice. Psychiatric Rehabilitation Journal, 30, 129 -136.

Clarke, S., Oades, L., Crowe, T., Caputi, P. \& Deane, F. P. (2009). The role of symptom distress and goal attainment in assisting the psychological recovery in consumers with enduring mental illness. Journal of Mental Health, 18, 389-397.

Clarke, S., Oades, L.G, Crowe, T.P. (accepted 19.7.2011). Recovery in mental health: a movement towards wellbeing and meaning in contrast with an avoidance of symptoms. Psychiatric Rehabilitation Journal.

College of Occupational Therapists (2006). Recovering Ordinary Lives: The Strategy for Occupational Therapy in Mental Health Services 2007-2017. College of Occupational Therapists: London.

Corrigan, P. W., Giffort, D., Rashid, F., Leary, M., \& Okeke, I. (1999). Recovery as a psychological construct. Community Mental Health Journal, 35, 231-239.

Crowe, T. P., Deane, F.P., Oades, L.G., Caputi, P. \& Morland, K.G. (2006). Effectiveness of a collaborative recovery training program in Australia in promoting positive views about recovery. Psychiatric Services, 57 (10), 1497-1500. 
Davidson, L., O'Connell, M., Tondora, J., Styron, T. \& Kangas, K. (2006). The Top 10 concerns about recovery encountered in mental health system transformation. Psychiatric Services, 57, 640-645.

Davidson L, Strauss JS. (1992). Sense of self in recovery from severe mental illness. British Journal of Medical Psychology, 65:131-145.

Davidson, L., Tondora, J., Staeheli Lawless, M., OConnell, M., \& Rowe, M. (2009). A practical guide to recovery-oriented practice. New York: Oxford University Press.

Deane, F. P., Crowe, T., King, R., Kavanagh, D., \& Oades, L. G. (2006). Challenges in implementing evidence-based practice into mental health services. Australian Health Review, 30, 305-309.

Deane, F.P., Glaser, N.M. Oades, L.G. \& Kazantzis, N. (2005). Psychologists' use of homework assignments with clients who have schizophrenia. Clinical Psychologist, 9 (1), 24-30.

Department of Health (2006). From Values to Action: The Chief Nursing Officer's Review of Mental Health Nursing. HMSO: London.

Department of Health (2001). The Journey to Recovery - The Government's Vision for Mental Health Care. Department of Health: London

Dweck, C.S. (2006). Mindset : The new psychology of success. New York : Random House.

Elliot, A. J. \& Friedman, R. (2007). Approach-avoidance: A central characteristic of personal goals. In B. R. Little, K. Salmela-Aro, \& S. D. Phillips (Eds.), Personal project pursuit: Goals, actions, and human flourishing (pp. 97-118). Mahwah, New Jersey: Lawrence Erlbaum Associates, Publishers.

Elliot, A. J., Sheldon, K. M. \& Church, M. A (1997). Avoidance personal goals and subjective well-being. Personality and Social Psychology Bulletin, 23, 915-927. doi: $10.1177 / 0146167297239001$

Frederickson, B.L. (2001). The role of positive emotions in positive psychology: The broaden and build theory. American Psychologist, 56, 218-226.

Green, L.S., Oades, L.G. Grant, A.M. (2006). Cognitive-Behavioural, Solution-Focused Life Coaching: Enhancing Goal Striving, Well-Being and Hope. Journal of Positive Psychology, 1(3), 142-149.

Hadikin, R., (2004). Effective coaching in healthcare. London: Elsevier Science.

Hayes, S.C. (2004). Acceptance and commitment therapy, relational frame theory, and the third wave of behavioural and cognitive therapies. Behaviour Therapy, 35(4), 639665.

Kazantzis, N., \& Deane, F. P. \& Ronan, K. (2000). Homework assignments in cognitive and behavioral therapy: A meta-analysis. Clinical Psychology: Science \& Practice, 7, 189202.

Kazantzis, N., Whittington, C., Dittilio, F. (2010). Meta-Analysis of Homework Effects in Cognitive and Behavioral Therapy: A Replication and Extension. Clinical Psychology: Science and Practice, 17, 2, 144-156.

Kelly, P., J. \& Deane, F. P. (2009). Does homework improve outcomes for individuals diagnosed with severe mental illness? Australian and New Zealand Journal of Psychiatry, 43, 968-975.

Keyes, C.L.M. (2002). The Mental health continuum: From languishing to flourishing in life. Journal of Health and Social Behavior, 43, 207-222. 
King, L. A. (1998). Personal goals and personal agency: Linking everyday goals to future images of the self. In M. Kofta, G. Weary \& G. Sedek (Eds.), Personal control in action: Cognitive and motivational mechanisms (pp.109-128). New York, NY: Plenum Press.

Lapsley H., Nikora L.W. \& Black R. (2002). Kia Mauri Tau! Narratives of Recovery from Disabling Mental Health Problems. Mental Health Commission: Wellington.

Linley, P.A. \& Harrington, S. (2006). Strengths coaching: A potential-guided approach to coaching psychology. International Coaching Psychology Review, 1(1), 37-46.

Magyar,-Moe, J.L. (2009). Therapist's guide to positive psychological interventions. New York: Elsevier.

Malachowski. C.K. (2009). Optimizing System and Patient Recovery. Rediscover and Recovery: The Shared Journey Project. International Journal of Psychosocial Rehabilitation, 13(2), 49-64.

Marshall, S., Oades, L., \& Crowe, T. (2009). Mental health consumers' perceptions of receiving recovery-focused services. Journal of Evaluation in Clinical Practice, 15, 654659.

Marshall, S., Oades, L., Crowe, T., Deane, F. P., \& Kavanagh, D. (2007). A review of consumer involvement in evaluations of case management: Consistency with a recovery paradigm. Psychiatric Services, 58, 396-401.

Martin DJ, Gaske JP, Davis MK. (2000). Relation of the therapeutic alliance with outcome and other variables: a meta-analytic review. Journal of Consulting and Clinical Psychology, 68: 438-450.

Maslow, A. H. (1987). Motivation and personality (3rd ed.). New York, NY: Harper and Row, Publishers.

Mental Health Commission (1998). Blueprint for Mental HealthServices in New Zealand. Mental Health Commission: Wellington.

Mental Health Commission (2005). A Vision for a Recovery Model in Irish Mental Health Services. Mental Health Commission: Dublin.

National Association of State Mental Health Program Directors (2006). Morbidity and mortality in people with serious mental illness. Medical Directors Council.

New Freedom Commission on Mental Health (2005). Achieving the Promise: Transforming Mental Health Care in America. U.S.Department of Health and Human Services: Rockville, MD.

Oades L.G., Andresen R., Crowe T.P., Malins G., Marshall S., and Turner A. (2008). A Handbook to Flourish: A Recovery-Based Self-Development Program. Illawarra Institute for Mental Health, University of Wollongong, NSW, Australia.

Oades, L., Crowe, T., Deane, F., Kavanagh, D., Lambert, W. G., \& Lloyd, C. (2005). Collaborative recovery: An integrative model for working with individuals who experience chronic and recurring mental illness. Australasian Psychiatry, 13, 279-284.

Oades, L.G. \& Crowe, T.P. (2008). Life Journey Enhancement Tools (Life JET). ISBN. 978-174128-156-9. Illawarra Institute for Mental Health, University of Wollongong.

Oades, L.G., Crowe, T.P. \& Nguyen, M. (2009). Leadership coaching transforming mental health systems from the inside out: The Collaborative Recovery Model as personcentred strengths based coaching psychology. International Coaching Psychology Review, 4(1), 25-36. 
Park, N. and Peterson, C.M. (2003). Virtues and organizations. In Cameron, K.S., Dutton, J.E., and Quinn, R.E. (Eds.) Positive Organizational Scholarship: Foundations of a New Discipline. San Francisco: Berrett-Koehler.

Petersen, C. \& Seligman, M.E.P. (2004). Character strengths and virtues: A handbook and classification. New York: Oxford University Press.

Piat, M., \& Sabetti, J. (2009). The Development of a Recovery-Oriented Mental Health System in Canada: What the Experience of Commonwealth Countries Tells Us. Canadian Journal of Community Mental Health. 28 (2), 17-33.

Quinn, N., \& Knifton, L. (2005). Promoting recovery and addressing stigma: Mental health awareness through community development in a low-income area. International Journal of Mental Health Promotion, 7, 37-44.

Rapp, C.A. (1998). The Strengths Model: Case management with people suffering from severe and persistent mental illness. New York: Oxford University Press.

Resnick, S.G. \& Rosenheck, R.A. (2006). Recovery and positive psychology: Parallel themes and potential synergies. Psychiatric Services, 57(1), 120-122.

Ryan, R.M., Huta, V., \& Deci, E.L. (2008). Living well: A self determination theory perspective on eudaimonia. Journal of Happiness Studies, 9, 139-170.

Salgado, D, Deane, F.P., Crowe, T.P. \& Oades, L.G. (2010). Hope and Improvements in Mental Health Service Providers' Recovery Attitudes Following Training. Journal of Mental Health, 19, 243-248.

Seligman, M. E. P., \& Csikszentmihalyi, M. (2000). Positive psychology: An introduction. American Psychologist, 55, 5-14.

Sheldon, K.M., Kasser, T., Simth, K., \& Share, T. (2002). Personal goals and psychological growth: Testing an intervention to enhance goal attainment and personality integration. Journal of Personality, 70(1), 5-31.

Slade, M. (2009). Personal recovery and mental illness. A guide for mental health professionals. Cambridge: Cambridge University Press.

Slade, M. (2010). Mental illness and well-being: The central importance of positive psychology and recovery approaches. BMC Health Services Research, 10, 26, http:/ / www.biomedcentral.com/1472-6963/10/26

Slade, M., Amering, M. \& Oades, L.G. (2008). Recovery: an international perspective. Epidemiologia e Psichiatria Sociale, 17(2), 128-137.

Smith-Merry, J., Freeman, R., \& Sturdy, S. (2011). Implementing recovery: an analysis of the key technologies in Scotland. International Journal of Mental Health Systems 2011, 5:11

Spaniol L, Wewiorski N, Gagne C, Anthony W.A. (2002). The process of recovery from schizophrenia. International Review of Psychiatry, 14:327-336.

Tooth BA, Kalyanansundaram V, Glover H. (1997). Recovery from schizophrenia: A consumer perspective. Final Report to Health and Human Services Research and Development Grants Program (RADGAC) Canberra: Department of Health and Aged Care.

Uppal, S., Oades, L.G., Crowe, T.P. \& Deane. F.P. (2010). Barriers to transfer of collaborative recovery training into clinical practice. Journal of Evaluation in Clinical Practice.16, 451-455.

Young SL, Ensing DS. (1999). Exploring recovery from the perspective of people with psychiatric disabilities. Psychiatric Rehabilitation Journal, 22:219-231. 


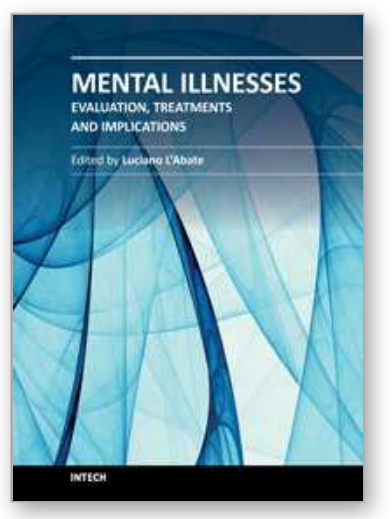

\author{
Mental IIInesses - Evaluation, Treatments and Implications \\ Edited by Prof. Luciano LAbate
}

ISBN 978-953-307-645-4

Hard cover, 476 pages

Publisher InTech

Published online 13, January, 2012

Published in print edition January, 2012

In the book "Mental Illnesses - Evaluation, Treatments and Implications" attention is focused on background factors underlying mental illness. It is crucial that mental illness be evaluated thoroughly if we want to understand its nature, predict its long-term outcome, and treat it with specific rather than generic treatment, such as pharmacotherapy for instance. Additionally, community-wide and cognitive-behavioral approaches need to be combined to decrease the severity of symptoms of mental illness. Unfortunately, those who should profit the most by combination of treatments, often times refuse treatment or show poor adherence to treatment maintenance. Most importantly, what are the implications of the above for the mental health community? Mental illness cannot be treated with one single form of treatment. Combined individual, community, and socially-oriented treatments, including recent distance-writing technologies will hopefully allow a more integrated approach to decrease mental illness world-wide.

\title{
How to reference
}

In order to correctly reference this scholarly work, feel free to copy and paste the following:

Lindsay G. Oades (2012). Responding to the Challenge of Mental Health Recovery Policy, Mental Illnesses Evaluation, Treatments and Implications, Prof. Luciano LAbate (Ed.), ISBN: 978-953-307-645-4, InTech, Available from: http://www.intechopen.com/books/mental-illnesses-evaluation-treatments-andimplications/responding-to-the-challenge-of-mental-health-recovery-policy

\section{INTECH}

open science | open minds

\section{InTech Europe}

University Campus STeP Ri

Slavka Krautzeka 83/A

51000 Rijeka, Croatia

Phone: +385 (51) 770447

Fax: +385 (51) 686166

www.intechopen.com

\section{InTech China}

Unit 405, Office Block, Hotel Equatorial Shanghai

No.65, Yan An Road (West), Shanghai, 200040, China

中国上海市延安西路65号上海国际贵都大饭店办公楼 405 单元

Phone: +86-21-62489820

Fax: $+86-21-62489821$ 
(C) 2012 The Author(s). Licensee IntechOpen. This is an open access article distributed under the terms of the Creative Commons Attribution 3.0 License, which permits unrestricted use, distribution, and reproduction in any medium, provided the original work is properly cited. 